\title{
Russell's Later Political Thought
}

It is quite clear that a major change took place in Russell's political thinking during (roughly) the last ten years of his life. In this article I wish to examine very briefly the nature of these changes and to consider some factors which might be held to account for them. Of course, the real need is for a documentary study of Russell's later politics, but I have neither sufficient space nor sufficient information for this task. As a result the present article can put forward only a few conjectures which may or may not prove well-founded when the definitive study of Russell's politics comes to be written.

One change in Russell's political position that received much attention during the 1960 s was his increasing sympathy for Russia. This dates originally from the death of Stalin in 1953 but was strengthened by the Cuban Crisis. During the Stalinist period Russell was generally more hostile to Russia than he was to the West (witness his much referred to and oft misquoted views on preventative war with Russia); after Stalin's death his attitude to Russia mellowed and his attitude to the West hardened. On questions of freedom and social organization he felt, by 1963, that there was little to choose between East and West; in foreign policy he supported whichever side he thought less bellicose which, as he said, was often Communist but not always so. (1) On the other hand, his differences with Communism remained considerable. So far as I know he never repudiated the critique of Marx which he presented in German Social Democracy (1896), The Practice and Theory of Bolshevism (1920), Freedom and Organization (1934) and Portraits from Memory (1956). He reiterated some of his criticisms and saw "no reason to recant" others in Unarmed Victory (pp. 13, 1516) - a book which was nonetheless condemned for his hopeless partiality towards Russia and China. Moreover, his sympathy towards the Communist countries was by no mean absolute. It reached its peak during the premiership of Khrushchev (no doubt partly due to his cordial personal relations with Khrushchev). After Khrushchev was deposed and the reinstatement of Stalinism begun in Russia, Russell's opposition to Soviet Communism revived and the Russian invasion of Czechoslovakia provoked his outright condemnation

Russell's attitude to Russia, however, seems to me more a symptom of a deeper change in his political position rather than a fundamental cause of it. What seems much more important was his view of the Cold War and the most decisive event in changing this was the Cuban Crisis. The unilateral Russian withdrawal from Cuba indicated to Russell that Russia, at least, had realized that there was nothing to be gained by nuclear war (see Unarmed Victory, p. 118). The signing of the partial nuclear test-ban treaty the following year gave a further indication that some lessons had been learnt. After the Cuban Crisis the danger of general war from nuclear brinkmanship receded. During the Cuban Crisis and immediately afterwards it was far from clear that this would be so, and in his conclusion to Unarmed Victory Russell gives no indication that this was more than a faint possibility. However, Russell was quick to appreciate that the post-Cuba turn of events was not an unrelieved blessing. Although the period of straight-forward East-West confrontation appeared to be over, a new and almost equally dangerous development had occurred, namely, the growth of American imperialism. These developments were set forth by Russell in an extremely perceptive essay, "The Cold War: A New Phase?"'(2) In this essay he makes it clear that this change was a result of the Russian withdrawal from Cuba: The Soviet Government realized at the time of the Cuban Crisis ... that, in a war between Russia and America, Russia, certainly, and America probably, would be ruined. This enabled the American Government to do things that were objectionable to the Russians.... Not only America, but the whole non-Communist West, could play a perpetual game of brinkmanship in which Russia had always to retreat. (op.cit., p. 77)

He also makes clear America's response to the new situation

It has come to be felt that a global nuclear war must be avoided....America, faced 
with this new situation, has developed a new policy, the aim of which is to transfer to possible of what used to ber Wherever Britain or France or Italy were involved in a difficult colonial war America would come to the assistance of the Power concerned and, by financial and military superiority, would gradually oust the former imperialist masters, thus replacing the former colonial empires with a puppet state of its own. (ibid., p. 76)

The overall nature of the conflict was thus changed from a simple East-West confrontation to a confrontation between the great powers and the smaller nations. At firs Russell treated it as a conflict between America and the Third World but with the invasion Russell treated culprits. The first clear of Czechoslovakia he came to think of Russia as am "Pece Through Resistance to Us statements of this point of view that I know are his essay "Peace Through Resistance to Us Imperialism" (January, 1966; reprinted in War Crimes in Vietnam) and the closely similar "Message to the First Solidarity Conference of the Peoples of Africa, Asia and Latin "Message to the First in the pieces the imperialist designs of America and America" (27 November 1965). In these two pieces the imperialist designs of America and affairs. (3) Russell even warns Russia lest she let the Third World down in her anxiety to keep the peace.

With a change in the overall structure of the Cold War Russell also detected a change in the details of the conflict. Crises were no longer like the Cuban Crisis, sudden and swiftly over, but long and drawn out, steadily escalating in brutality and horror, like the Vietnam War. In an interesting interview with Enrique Raab (printed in two parts in the London Sunday Citizen on 31 October and 7 November 1965) Raab asked Russell if he saw any differences between the Kennedy-Khrushchev era and the Johnson-Breznev era. At first Russell replied "Not too many." But then he added:

In the Kennedy-Krushchev era, the crises were fast and fulminating. Look at the Cuban episode. Now they tend to be slower, to drag on for month after month, and to acquire a degree of dangerous infection. Yes, in this sense I think there is a danger. This slow suppuration is psychologically more harmful.

Realizing that things were different Russell espoused different ideals and different methods of achieving them. In Has Man a Future? (1961) and in the final pages of Unarmed Victory (1963) Russell advocated world government. In the Raab interview just quoted he was much more pessimistic about its chances of success. Thereafter, so far as I know, he never thought of it as a viable alternative: more likely he saw it as a tool whereby the super powe substituted the hope that the smaller and that public opinion within the great powers would help to render them innocuous. This resulted in an almost complete volte face on the question of nationalism: Russell had previously opposed nationalism and hoped that world government would subdue it as an international force; he ended by supporting nationalism as the only defence against iminternational force; he ended by supporting nationalism as the only defence agatere he said that "the disaster started" with Patrick Henry's slogan "Death before dependence on the British Crown", with War Crimes in Vietnam (p. 122), where he said that the patriots of the Bme liberty or give me death", the American rev very idea which motivated the Vietnamese in their heroic resistance to America. (Less than a year separates the two statements. It needs to be noted that the second passage occurs in an appeal to Americans to take a more reasonable view of the Vietnam War.)

Russell's new political position, which he continued to expound with an ever increasing urgency and bitterness, earned him more vilification than almost any other of his political statements (with the exception of his pacifist writings during the First World War). But his position has since been accepted by many radicals and his views on international But his port in line with the thinking of the New Left. It is a matter for amazement that in Russell in his nineties had the mental flexibility to recognize so quickly long term changes in the international situation at a time when many radicals continued to think in terms of the orthodox Cold War confrontation. Yet it may be questioned whether Russell's influence on the New Left was very deep. Certainly the New Left found no intellectual roots in Russell's writings on political theory, but rather in a deviation of Marxism which Russell had always in general vehemently opposed. Their agreement was limited to practical politics alone, but there the agreement was wider than on foreign policy alone. Russell lent his support to the movement for workers' control (a subject on which he had written during and just after the First World War) and to the student protest movement (witness his telegram of support to the Hull students during the sit-in in 1968).

The change in his writings from urbanely good-humoured satire to an increasingly American policy has often been noted with regret. icles in War Crimes i ticles in War Crimes in Vietnam are most unlikely to persuade a member of the alleged "silent majority" to change his views. This, it has been suggested, was the reason for the decline of Russell's influence on the establishment. On the other hand, it may equally well be seen as the result of the decline of his influence. War Crimes in Vietnam, in particular was greeted as a work of hopelessly biassed fanaticism. Unfortunately, since its publication the revelations of My Lai have confirmed in essence his account of American behaviour, whilst the publication of The Pentagon Papers has revealed that Russell, if anything, underestimated the cynicism of American policy. The nature of the War was further revealed by the War Crimes Tribunal of 1967. With some justification Russell said after My Lai, "All this and much more was known years ago to anyone concerned to learn the truth."'(4)

There were doubtless other causes of the extreme tone of Russell's last writings, particularly on Vietnam. (Although even in this case, it is interesting to note, his tone was not as strident as that of Gladstone in his pamphlet on The Bulgarian Horrors (1876) about a situation in some ways similar to Vietnam.) Russell was faced by a government that was imperturbable in its incorrigibility, a press that was unwilling to print the truth, and a public which was in consequence both ill-informed and apathetic. On the other hand there was a situation in Vietnam which beggared the imagination in its cruelty and horror. Russell was an old man in his nineties who realized that his ability to influence events and the time available for him to do so were strictly limited. The result was an intolerable combination of moral outrage and frustration. At times, reading War Crimes in Vietnam, one gets the impression that words were in danger of failing him. The result was an in creasingly bitter denunciation of American policy. In these circumstances it became im possible for him to maintain his old wit and urbanity, and the loss of these qualities gave his works an air of fanaticism. Unfortunately, this apparent fanaticism made it easier for the establishment to ignore him. His great achievement, however, is tha now, in somer the almost ten years after he wrote, the nature of the American war in Vietnam has become widely known, the credibility of the American government's statements about the War has been destroyed, and international protest (coupled with military failure) is forcing American withdrawal from, in Gladstone's phrase, "a province they have desolated and profaned".

A further feature of War Crimes in Vietnam that has been remarked is its excessive documentation. It is quite the most heavily documented of all Russell's political books, sometimes (as in "Free World Barbarism", first published in December 1964) quotation, seems to swamp the argument. The reason for this is clear. Russell was not dealing with a crisis about which the major facts were well-known as was the case in the Cuban Crisis. The most important facts about Vietnam had been suppressed and denied and distorted by both government and press. Russell's first task was to make these facts clear. He bnew from bitter experience that his word would not be taken for it, and and that the answer lay in the extensive use of documentation from on-the-spot observers. The War Crimes Tribunal was his most massive effort in this direction.(5)

A final issue needs to be mentioned although there is, as yet, no possibility of This is the question of the influence of yis addisessibility of years of his life. It has been alleged that his secretary, Ralph Schoenman, exercised an 
influence on Russell not unlike that exercised by Chertkov on Tolstoy. These allegations are serious and have been denied by both Schoenman and Russell. Schoenman wrote, in his reply to Adam Roberts already mentioned, "The attribution to me of Russell's words, thoughts, writings, political actions are a form of flattery I can do without." But it would not be unduly surprising if, as Russell's political work became more institutionalized after the formation of the Bertrand Russell Peace Foundation, statements issued by the Foundation were sent out over Russell's signature though he himself had not written them. It seems unlikely either that Russell allowed himself to be dominated by his advisers, or that they were completely without influence on him. We will not be able to assess the extent of their influence for some time yet.

The suggestions made in this article are based on an inadequate sampling of the more easily available, published documents on the subject. The Bertrand Russell Archives possess an enormous and growing number of statements, records of conversations and letters which will provide a much more detailed and continuous narrative of Russ political involvement. A definitive assessment of his political career cannot be made uru these have been studied.

Research School of Social Sciences

Nicholas Griffin Australian National University

(1) Cf. Unarmed Victory (Penguin, 1963), pp. 12-13, 15-16.

(2) This essay was written in November 1964 and is printed in War Crimes in Vietnam (Allen and Unwin, 1967)

(3) In earlier articles, e.g., "Free World Barbarism" and "Danger in South-East Asia" (both in War Crimes in Vietnam), this view is hinted at but not explicitly stated.

(4) “On American Violence", Ramparts, 8: March 1970, p. 56; The Spokesman, no. 2: April 1970, p. 4

(5) It is only fair to mention that there is some dispute as ritical in his use of sources. See Adam Roberts, "Bertrand Russell and the Vietnam Tribunal", New Society, 9: 2 February 1967, pp. 156-9. But see also Ralph Schoenman's reply in New Society, 9: 30 March 1967, pp. 476-7. Schoenman's reply is not, in all respects, satisfactory. 